\title{
Prognostic value of serum $\alpha$-fetoprotein in ovarian yolk sac tumors: A systematic review and meta-analysis
}

\author{
YANG-LONG GUO, YING-LI ZHANG and JIAN-QING ZHU \\ Department of Gynecologic Oncology, Zhejiang Cancer Hospital, Hangzhou, Zhejiang 310022, P.R. China
}

Received May 20, 2014; Accepted September 3, 2014

DOI: $10.3892 / \mathrm{mco} .2014 .417$

\begin{abstract}
This study was conducted to determine the prognostic value of serum $\alpha$-fetoprotein (AFP) levels in patients with ovarian yolk sac tumor (OYST). We performed a systematic review and meta-analysis to assess the associations between serum AFP level and prognosis in OYST. A total of 12 quantitative studies met the inclusion criteria. Preoperative AFP was not found to be associated with overall survival (OS) [odds ratio $(\mathrm{OR})=0.84,95 \%$ confidence interval $(\mathrm{CI}): 0.43-1.62]$ in OYST. However, a high postoperative AFP level was associated with worse $\mathrm{OS}(\mathrm{OR}=0.16,95 \% \mathrm{CI}$ : 0.05-0.48) and relapse-free survival (RFS) $(\mathrm{OR}=0.18,95 \% \mathrm{CI}$ : 0.08-0.43) compared to a low postoperative AFP level in patients with OYST. In addition, a postoperative AFP level of $>1,000 \mathrm{ng} / \mathrm{ml}$ was associated with a decrease in $\mathrm{OS}(\mathrm{OR}=0.16,95 \% \mathrm{CI}$ : $0.05-0.50)$ and RFS (OR=0.21, 95\% CI: 0.08-0.57). In conclusion, the postoperative, but not the preoperative, AFP level was found to be a prognostic factor in patients with OYST. In particular, a postoperative AFP level of $>1,000 \mathrm{ng} / \mathrm{ml}$ was an indicator of poor prognosis in patients with OYST.
\end{abstract}

\section{Introduction}

Ovarian yolk sac tumor (OYST), also referred to as ovarian endodermal sinus tumor, is a rare malignant tumor typically occurring in adolescent and young adult women. OYSTs comprise $\sim 1 \%$ of ovarian malignancies $(1,2)$. In addition, OYST is a highly malignant germ cell tumor, characteristically expressing $\alpha$-fetoprotein (AFP). AFP is a useful tumor marker for detecting malignancies such as hepatocellular carcinoma, yolk sac tumor and a specific type of gastric carcinoma. An

Correspondence to: Dr Jian-Qing Zhu or Dr Ying-Li Zhang, Department of Gynecologic Oncology, Zhejiang Cancer Hospital, 38 Guangji Road, Hangzhou, Zhejiang 310022, P.R. China

E-mail: zhujq@zjcc.org.cn

E-mail: pandazhang@163.com

Abbreviations: AFP, $\alpha$-fetoprotein; OYST, ovarian yolk sac tumor; OS, overall survival; OR, odds ratio; CI, confidence interval; RFS, relapse-free survival; BEP, bleomycin, etoposide and cisplatin

Key words: ovarian yolk sac tumor, $\alpha$-fetoprotein, prognosis elevated serum AFP level is usually detected in patient with OYST and may facilitate diagnosis (2).

The prognosis of OYST was extremely dismal in the past $(3,4)$. Over the last few decades, with the introduction of novel combination chemotherapy, the prognosis of OYST has significantly improved; however, its prognosis remains unsatisfactory. Furthermore, little is known regarding the prognostic factors of OYST, due to the rarity of this type of tumor. The number of studies that have analyzed the prognostic factors of OYST is currently limited, while the rare published series on OYST usually include $<50$ cases $(2,3,5-7)$. Certain studies presented evidence of the association between serum AFP level and the prognosis of OYST. Mitchell et al (8) reported that a shorter relapse-free survival (RFS) was primarily observed among patients with AFP $>1,000 \mathrm{kU} / 1$ compared to that among patients with AFP $\leq 1,000 \mathrm{kU} / 1$ [odds ratio $(\mathrm{OR})=0.09$, 95\% confidence interval (CI): 0.01-0.85]. In addition, de La Motte Rouge et al (9) demonstrated that there was a significant association between high serum AFP levels and 5-year overall survival (OS) of OYST (OR=0.24; 95\% CI: 0.05-1.19). By contrast, other studies failed to demonstrate that AFP was a prognostic factor in patients with OYST $(1,6,10)$.

Therefore, the objective of the present study was to perform a meta-analysis of the association between serum AFP levels and the prognosis of OYST.

\section{Materials and methods}

Literature search. A systematic review of original articles analyzing the prognostic value of AFP for OYST was performed through searching MEDLINE (1946 to August, 2013) and EMBASE (1980 to August, 2013). The search terms used were 'ovarian neoplasm', 'ovarian masses', 'ovarian lesions' and 'alpha fetoprotein/AFP', combined with the MeSH term 'prognosis' (disease-free survival, relapse-free survival, overall survival, progression-free survival, medical futility, neoplasm grading, neoplasm staging, nomograms, pregnancy outcome, treatment outcome and treatment failure). The search was limited to human studies and reports in languages other than English were excluded. Moreover, the reference lists of the available studies were reviewed to identify additional relevant citations. The study selection process is summarized in Fig. 1.

Inclusion criteria. The inclusion criteria were as follows: i) pathological diagnosis of YST or mixed YST; ii) serum AFP 




Figure 1. Flowchart of study selection process.

level was obtained; iii) original article published in English; and iv) survival data obtained, with $\geq 12$ months of follow-up.

Exclusion criteria. The exclusion criteria were as follows: i) incomplete data; ii) animal studies; iii) duplicate studies; iv) reviews, letters and comments; v) low-quality articles; and vi) results presented as abstracts only.

Data extraction. English articles meeting the inclusion criteria were regularly assessed by pairs of reviewers. Any differences were discussed until the two reviewers reached a consensus. We recorded publication reference, tumor types (OYST or other tumors), mean patient age, study design, statistical techniques, country, total number of participants, characteristics of AFP, outcome reported (OS and RFS), mean follow-up and confounding factors. The characteristics of the studies included in this meta-analysis are summarized in Table I and detailed data for each study are provided in Table II.

Exposure measurements. We recorded the characteristics of AFP, including value, types and standard classification from each study and classified different groups according to the characteristics of AFP among studies. Certain studies reported on preoperative or postoperative AFP level for each patient, whereas others reported the total number of patients in each group, divided by preoperative or postoperative AFP level. We calculated the OR of higher vs. lower AFP level by comparing the outcomes in the two groups. The standard of higher and lower AFP level was based on the respective standard from each study.

Study quality. The quality of each study was assessed using a subset of items from Quality Assessment of Diagnostic
Accuracy Studies 2 (19). We estimated the criteria as follows: type of study design, patient selection by diagnostic protocol, exposure measurement (characteristics of AFP, comparability of measurement across the study groups, follow-up time, validity and reliability of the measurement method), statistical analysis (appropriateness) and adjustment for key confounders (primary surgery and combination chemotherapy).

Statistical analysis. Pooled ORs of AFP level with 95\% CIs for OS and RFS were obtained using the fixed- or random-effects models. The $\mathrm{Q}$ and $\mathrm{I}^{2}$ statistics were used to assess heterogeneity, where $\mathrm{P} \leq 0.05$ or $\mathrm{I}^{2}>50 \%$ were considered to indicate significant heterogeneity. When the result of the Q-test and $\mathrm{I}^{2}$ statistics suggested heterogeneity $\left(\mathrm{P} \leq 0.05\right.$ and $\left.\mathrm{I}^{2}>50 \%\right)$, a random-effects model was used. We used either fixed- or random-effects models in pooled estimates. Furthermore, we preferentially presented a random-effects model when heterogeneity was present. We also created forest plots for the ORs from each of the studies included in the meta-analysis and the estimation of the pooled OR. The sizes of the markers of each OR in the plots indicated the relative weight each study contributed to the pooled estimation. Publication bias was estimated by funnel plots, Begg's test and a weighted Egger's test (20). In addition, we produced sensitivity analyses, whereby each study was omitted in turn, reevaluating the pooled estimates under particular conditions. All the analyses were performed using STATA software, version 12.0 (StataCorp LP, College Station, TX, USA).

\section{Results}

Study characteristics. This meta-analysis included 12 studies reporting on 19 independent estimates. There were 320 participants from 9 different countries (3 studies from Japan, 2 from China and 1 each from Denmark, Holland, Italy, Spain, America, France and United Kingdom). Five studies reported preoperative AFP and OS; OS was assessed by 2- $(n=1), 3-$ $(n=1)$ and 5-year OS $(n=3)$. Six studies reported postoperative AFP and OS; OS was assessed by $1-(n=3), 2-(n=2)$ and 5-year OS $(n=1)$. Eight studies reported postoperative AFP and RFS; RFS was assessed by $1-(n=3), 2-(n=4)$ and 5-year RFS $(n=1)$. The follow-up time ranged between 14 and 71 months.

Association between preoperative AFP and OS in OYST. We conducted a meta-analysis for 5 studies on preoperative AFP and OS (Table II). Heterogeneity tests revealed no evidence of heterogeneity among studies $\left(\mathrm{Q}=5.35, \mathrm{P}=0.253, \mathrm{I}^{2}=25.3 \%\right)$. Therefore, the fixed-effects model was used to calculate a pooled OR with $95 \% \mathrm{CI}$. We failed to identify a correlation of preoperative AFP with OS (OR=0.84, 95\% CI: 0.43-1.62) in OYST. A forest plot is shown in Fig. 2A. A funnel plot is shown in Fig. 3A and it exhibits near symmetry. The Begg's and Egger's tests indicated that publication bias was unlikely $(\mathrm{Zc}=0.73, \mathrm{P}=0.462 ; \mathrm{t}=1.24, \mathrm{P}=0.303)$. A sensitivity analysis demonstrated that the results for preoperative AFP and OS in these studies were not robust, due to the Umezu et al (18) study, which exhibited significant heterogeneity (Table III).

Association between postoperative AFP and OS in OYST. Six studies were included (Table II). Heterogeneity tests revealed 
Table I. Characteristics of the studies included in the meta-analysis.

\begin{tabular}{|c|c|c|c|c|c|}
\hline First author & $\begin{array}{l}\text { Mean age } \\
\text { (years) }\end{array}$ & $\begin{array}{l}\text { Study } \\
\text { design }\end{array}$ & Statistical analysis & Country & (Refs.) \\
\hline Sell et al & 28.2 & Retrospective & Case description & Denmark & (11) \\
\hline Talerman et al & 15.9 & Retrospective & Case description & Holland & $(12)$ \\
\hline Sessa et al & 17.2 & Retrospective & Case description & Italy & (13) \\
\hline Sasaki et al & 20.1 & Retrospective & Cox proportional hazard models & Japan & (14) \\
\hline Nogales et al & 58.3 & Retrospective & Case description & Spain & $(15)$ \\
\hline Davidoff et al & 3.8 & Retrospective & Case description & America & $(16)$ \\
\hline Chen et al & 15.1 & $\begin{array}{c}\text { Retrospective } \\
\text { (case-control study) }\end{array}$ & Case description & China & $(17)$ \\
\hline Mitchell et al & 21 & Retrospective & Log-rank test and Cox's regression & UK & (8) \\
\hline Nawa et al & NK & Prospective & Logistic regression & Japan & $(6)$ \\
\hline Umezu et al & NK & Retrospective & Log-rank test & Japan & $(18)$ \\
\hline Tong et al & NK & Retrospective & Cox proportional hazard model & China & $(10)$ \\
\hline de La Motte Rouge et al & NK & Retrospective & Cox proportional hazard regression & France & (9) \\
\hline
\end{tabular}

NK, not known.

Table II. Detailed data of the studies included in the meta-analysis.

\begin{tabular}{|c|c|c|c|c|c|c|}
\hline First author (year) & Subjects & $\begin{array}{c}\text { Characteristics } \\
\text { of AFP }\end{array}$ & Outcomes & $\begin{array}{c}\text { Mean } \\
\text { follow-up } \\
\text { (months) }\end{array}$ & Controlled factors & (Refs.) \\
\hline Sell et al (1976) & 8 & Postoperative & $\begin{array}{l}\text { 1-year OS and } \\
1 \text {-year RFS }\end{array}$ & 14 & $\begin{array}{l}\text { Primary surgery and } \\
\text { AFP determination }\end{array}$ & $(11)$ \\
\hline Talerman et al (1978) & 9 & $\begin{array}{l}\text { Preoperative and } \\
\text { postoperative }\end{array}$ & $\begin{array}{l}\text { 2-year OS and } \\
\text { 2-year RFS }\end{array}$ & 24 & Primary surgery & (12) \\
\hline Sessa et al (1987) & 13 & Postoperative & 2-year RFS & 36 & $\begin{array}{l}\text { Primary surgery and } \\
\text { combination chemotherapy }\end{array}$ & (13) \\
\hline Sasaki et al (1994) & 27 & Preoperative & 3-year OS & 28 & $\begin{array}{l}\text { Histopathological diagnosis } \\
\text { and combination chemotherapy }\end{array}$ & (14) \\
\hline Nogales et al (1996) & 6 & Postoperative & $\begin{array}{l}\text { 1-year OS and } \\
\text { 1-year RFS }\end{array}$ & 14 & Primary surgery & $(15)$ \\
\hline Davidoff et al (1996) & 6 & Postoperative & $\begin{array}{l}\text { 2-year OS and } \\
\text { 2-year RFS }\end{array}$ & 53 & $\begin{array}{l}\text { Primary surgery and } \\
\text { combination chemotherapy }\end{array}$ & $(16)$ \\
\hline Chen et al (1997) & 6 & Postoperative & $\begin{array}{l}\text { 1-year OS and } \\
\text { 1-year RFS }\end{array}$ & 12 & $\begin{array}{l}\text { Primary surgery and combination } \\
\text { chemotherapy. Liver metastasis }\end{array}$ & $(17)$ \\
\hline Mitchell et al (1999) & 41 & Postoperative & 2-year RFS & 68 & Platinum-based chemotherapy & (8) \\
\hline Nawa et al (2001) & 42 & Preoperative & 5-year OS & 60 & $\begin{array}{l}\text { Primary surgery and } \\
\text { combination chemotherapy }\end{array}$ & (6) \\
\hline Umezu et al (2008) & 36 & Preoperative & 5-year OS & 60 & $\begin{array}{l}\text { Primary surgery and } \\
\text { combination chemotherapy }\end{array}$ & (18) \\
\hline Tong et al (2008) & 53 & Preoperative & 5-year OS & 60 & $\begin{array}{l}\text { Primary surgery and } \\
\text { combination chemotherapy }\end{array}$ & (10) \\
\hline $\begin{array}{l}\text { de La Motte Rouge } \\
\text { et al (2011) }\end{array}$ & 73 & Postoperative & $\begin{array}{l}\text { 5-year OS and } \\
\text { 5-year RFS }\end{array}$ & 71 & Primary surgery & (9) \\
\hline
\end{tabular}

AFP, $\alpha$-fetoprotein; OS, overall survival; RFS, relapse-free survival. 
A Study

ID

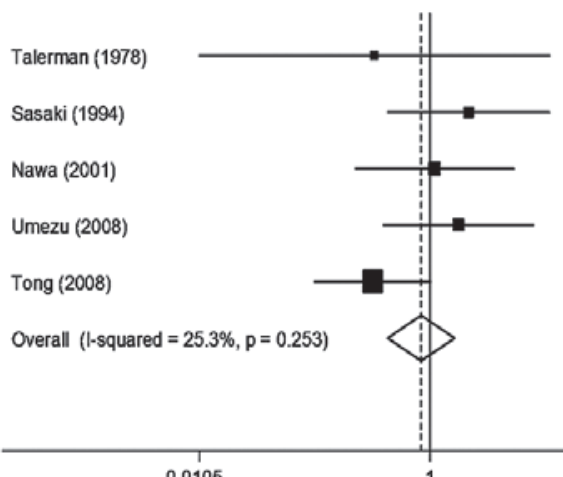

0.0105

B Study

ID

Sell (1976)

Talerman (1978)

Nogales (1996)

Davidoff (1996)

Chen (1997)

de La Motte Rouge (2011)

Overall (l-squared $=0.0 \%, p=0.732)$

C Study

ID

Sell (1976)

Talerman (1978)

Sessa (1987)

Nogales (1996)

Davidoff (1996)

Chen (1997)

Mitchell (1999)

de La Motte Rouge (2011)

Overall (l-squared $=0.0 \%, p=0.779$ )
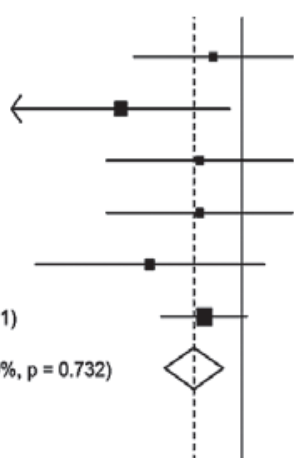

1

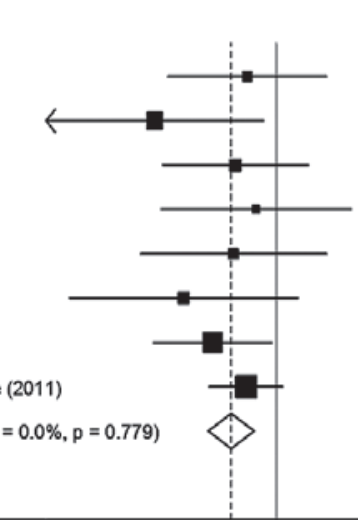

0.00017

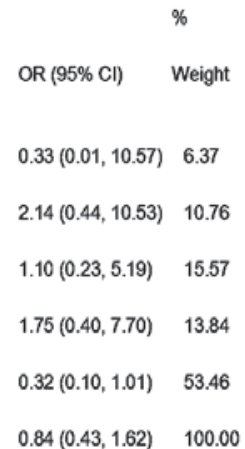

95.2
OR $(95 \% \mathrm{Cl}) \quad$ Weight

$0.33(0.02,6.65) \quad 8.07$

$0.01(0.00,0.62) \quad 24.21$

$0.20(0.01,6.66) \quad 8.41$

$0.20(0.01,6.66) \quad 8.41$

$0.03(0.00,2.27) \quad 11.10$

$0.24(0.05,1.19) \quad 39.80$

$0.16(0.05,0.48) \quad 100.00$

6053

\begin{tabular}{cc} 
OR $(95 \% \mathrm{Cl})$ & Weight \\
$0.33(0.02,6.65)$ & 5.53 \\
$0.01(0.00,0.62)$ & 16.60 \\
$0.21(0.01,3.37)$ & 7.95 \\
$0.47(0.01,16.89)$ & 3.46 \\
$0.20(0.01,6.66)$ & 5.77 \\
$0.03(0.00,2.27)$ & 7.61 \\
$0.09(0.01,0.85)$ & 23.76 \\
$0.32(0.08,1.28)$ & 29.32 \\
$0.18(0.08,0.43)$ & 100.00 \\
& \\
\hline 6053 &
\end{tabular}

Figure 2. Forest plots of meta-analysis in different design methods. (A) Effect of preoperative $\alpha$-fetoprotein (AFP) level on overall survival (OS). (B) Effect of postoperative AFP level on OS. (C) Effect of postoperative AFP level on relapse-free survival. OR, odds ratio; CI, confidence interval.

no evidence of heterogeneity among studies $(\mathrm{Q}=2.79, \mathrm{P}=0.732$, $\mathrm{I}^{2}=0.0 \%$; therefore, the fixed-effects model was used to assess a pooled OR with $95 \% \mathrm{CI}$. We observed that a high postoperative AFP level was associated with a decrease in OS $(\mathrm{OR}=0.16$, 95\% CI: 0.05-0.48). A high postoperative AFP level was associated with a worse OS compared to a low postoperative AFP level in patients with OYST. A forest plot is shown in Fig. 2B. A funnel plot is shown in Fig. 3B and it exhibits near symmetry. The Begg's and Egger's tests indicated that publication bias was unlikely in the meta-analysis on association between postoperative AFP and OS in these studies $(\mathrm{Zc}=1.31, \mathrm{P}=0.189$; $\mathrm{t}=-1.47, \mathrm{P}=0.217)$. A sensitivity analysis demonstrated that the pooled estimate of the effect of postoperative AFP level on the risk of OS was robust, as shown in Table III.

Association between postoperative AFP and RFS in OYST. We performed a meta-analysis of 8 studies on postoperative AFP and RFS (Table II). Heterogeneity tests revealed no evidence of heterogeneity among studies $(\mathrm{Q}=4.01, \mathrm{P}=0.779$, $\mathrm{I}^{2}=0.0 \%$ ); therefore, the fixed-effects model was used to estimate a pooled OR with $95 \%$ CI. We observed that a high postoperative AFP level was associated with a decrease in 

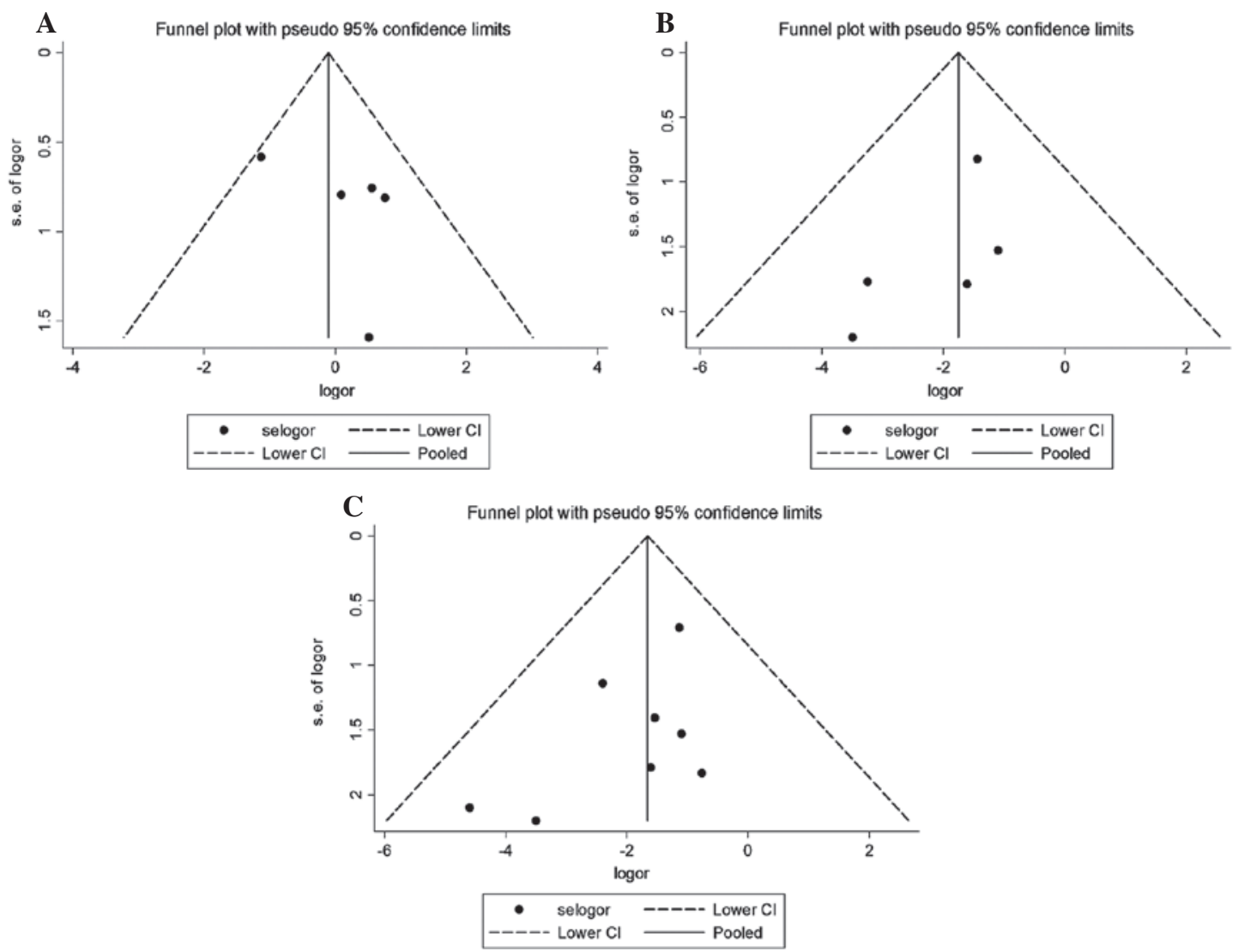

Figure 3. Funnel plots of meta-analysis in different design methods. (A) Effect of preoperative $\alpha$-fetoprotein (AFP) level on overall survival (OS). (B) Effect of postoperative AFP level on OS. (C) Effect of postoperative AFP level on relapse-free survival. SE, standard error; OR, odds ratio; CI, confidence interval.

RFS (OR=0.18, 95\% CI: 0.08-0.43). A high postoperative AFP level was associated with a worse RFS compared to low postoperative AFP level in patients with OYST. A forest plot is shown in Fig. 2C. A funnel plot is shown in Fig. 3C and it exhibits near symmetry. The Begg's and Egger's tests indicated that publication bias was unlikely in the meta-analysis on association between postoperative AFP and RFS in these studies $(\mathrm{Zc}=1.11, \mathrm{P}=0.266 ; \mathrm{t}=-1.61, \mathrm{P}=0.159)$. A sensitivity analysis demonstrated that the result was robust, as shown in Table III

Subgroup analysis of postoperative AFP and $O S$. We conducted a meta-analysis of 8 studies on postoperative AFP and OS (Table IV). Heterogeneity tests revealed no evidence of heterogeneity among studies $\left(\mathrm{Q}=2.78, \mathrm{P}=0.595, \mathrm{I}^{2}=0.0 \%\right)$; therefore, the fixed-effects model was used to calculate a pooled OR with $95 \%$ CI. In the design that was used, a high postoperative AFP level was associated with a decrease in OS (OR=0.16, 95\% CI: 0.05-0.50). A postoperative AFP level of $>1,000 \mathrm{ng} / \mathrm{ml}$ was associated with a worse OS compared to an AFP level of $\leq 1,000 \mathrm{ng} / \mathrm{ml}$ in patients with OYST. A forest plot is shown in Fig. 4A. The Begg's and Egger's tests indicated that publication bias was unlikely in the meta-analysis of the association between postoperative AFP and OS in these studies $(\mathrm{Zc}=1.22, \mathrm{P}=0.221 ; \mathrm{t}=-1.48, \mathrm{P}=0.236)$.

Subgroup analysis of postoperative AFP and RFS. Eight studies were included (Table IV). Heterogeneity tests revealed no evidence of heterogeneity among studies $(\mathrm{Q}=3.50, \mathrm{P}=0.623$,
$\left.\mathrm{I}^{2}=0.0 \%\right)$; therefore, the fixed-effects model was used to calculate a pooled OR with $95 \%$ CI. In the design that was used, a high postoperative AFP level was associated with a decrease in $\mathrm{RFS}(\mathrm{OR}=0.21,95 \% \mathrm{CI}$ : $0.08-0.57)$. A postoperative AFP level of $>1,000 \mathrm{ng} / \mathrm{ml}$ was associated with a worse RFS compared to an AFP level of $\leq 1,000 \mathrm{ng} / \mathrm{ml}$ in patients with OYST. A forest plot is shown in Fig. 4B. The Begg's and Egger's tests indicated that publication bias was unlikely in the meta-analysis on the association between postoperative AFP and RFS in these studies $(\mathrm{Zc}=1.11, \mathrm{P}=0.266$; $\mathrm{t}=-1.61, \mathrm{P}=0.159)$.

\section{Discussion}

OYST is a rare malignancy, occurring most commonly in young women. AFP is an important tumor marker of yolk sac tumors. Moreover, an elevation of the serum AFP level is usually detected in patient with YST and is correlated with the severity of the disease. Due to the extreme sensitivity of AFP in diagnosing recurrence, the follow-up of the patients mainly includes measuring AFP levels (2).

Our study demonstrated that preoperative AFP was not a prognostic factor in patients with OYST. We failed to identify a correlation between preoperative AFP level and OS (OR=0.84, 95\% CI: 0.43-1.62) in OYST, which may be due to the fact that preoperative AFP levels may only reflect the condition of the primary disease, but have a limited impact on patient outcome. Surgical resection of the tumor and chemosensitivity may be key to a successful treatment in patients with OYST. It is 
Table III. Sensitivity analysis of the associations between AFP and outcomes.

\begin{tabular}{|c|c|c|c|c|c|c|c|}
\hline AFP and outcome & Subjects & Model & OR $(95 \% \mathrm{CI})$ & Q & P-value & $\mathrm{I}^{2}(\%)$ & (Refs.) \\
\hline \multicolumn{8}{|l|}{ Preoperative AFP and OS } \\
\hline Total & 167 & Fixed-effects & $0.84(0.43-1.62)$ & 5.35 & 0.253 & 25.3 & \\
\hline Talerman et al excluded & 9 & Fixed-effects & $0.87(0.44-1.71)$ & 5.07 & 0.167 & 40.8 & (12) \\
\hline Sasaki et al excluded & 27 & Fixed-effects & $0.68(0.32-1.42)$ & 3.72 & 0.293 & 19.4 & (14) \\
\hline Nawa et al excluded & 42 & Fixed-effects & $0.79(0.38-1.64)$ & 5.22 & 0.157 & 42.5 & (6) \\
\hline Umezu et al excluded & 36 & Fixed-effects & $0.69(0.33-1.46)$ & 4.16 & 0.245 & 27.8 & (18) \\
\hline Tong et al excluded & 53 & Fixed-effects & $1.43(0.62-3.31)$ & 1.11 & 0.774 & 0.0 & (10) \\
\hline \multicolumn{8}{|l|}{ Postoperative AFP and OS } \\
\hline Total & 108 & Fixed-effects & $0.16(0.05-0.48)$ & 2.79 & 0.732 & 0.0 & \\
\hline Sell et al excluded & 8 & Fixed-effects & $0.15(0.04-0.48)$ & 2.54 & 0.638 & 0.0 & (11) \\
\hline Talerman et al excluded & 9 & Fixed-effects & $0.21(0.05-0.68)$ & 0.89 & 0.926 & 0.0 & (12) \\
\hline Nogales et al excluded & 6 & Fixed-effects & $0.16(0.05-0.50)$ & 2.78 & 0.595 & 0.0 & (15) \\
\hline Davidoff $e t$ al excluded & 6 & Fixed-effects & $0.16(0.05-0.50)$ & 2.78 & 0.595 & 0.0 & (16) \\
\hline Chen et al excluded & 6 & Fixed-effects & $0.18(0.06-0.55)$ & 2.17 & 0.705 & 0.0 & $(17)$ \\
\hline de La Motte Rouge et al excluded & 73 & Fixed-effects & $0.11(0.03-0.50)$ & 2.39 & 0.665 & 0.0 & $(9)$ \\
\hline \multicolumn{8}{|l|}{ Postoperative AFP and RFS } \\
\hline Total & 162 & Fixed-effects & $0.18(0.08-0.43)$ & 4.01 & 0.779 & 0.0 & \\
\hline Sell et al excluded & 8 & Fixed-effects & $0.17(0.07-0.43)$ & 3.86 & 0.695 & 0.0 & (11) \\
\hline Talerman et al excluded & 9 & Fixed-effects & $0.22(0.09-0.54)$ & 1.94 & 0.925 & 0.0 & (12) \\
\hline Sessa et al excluded & 13 & Fixed-effects & $0.18(0.07-0.45)$ & 4.00 & 0.676 & 0.0 & (13) \\
\hline Nogales et al excluded & 6 & Fixed-effects & $0.17(0.07-0.42)$ & 3.75 & 0.710 & 0.0 & (15) \\
\hline Davidoff $e t$ al excluded & 6 & Fixed-effects & $0.18(0.07-0.44)$ & 4.01 & 0.675 & 0.0 & (16) \\
\hline Chen et al excluded & 6 & Fixed-effects & $0.20(0.08-0.47)$ & 3.29 & 0.772 & 0.0 & (17) \\
\hline Mitchell et al excluded & 41 & Fixed-effects & $0.21(0.08-0.54)$ & 3.50 & 0.744 & 0.0 & $(8)$ \\
\hline de La Motte Rouge et al excluded & 73 & Fixed-effects & $0.13(0.04-0.39)$ & 3.07 & 0.799 & 0.0 & (9) \\
\hline
\end{tabular}

AFP, $\alpha$-fetoprotein; OR, odds ratio; CI, confidence interval; OS, overall survival; RFS, relapse-free survival.

Table IV. Detailed data of the studies included in the subgroup meta-analysis.

\begin{tabular}{|c|c|c|c|c|c|c|}
\hline First author (year) & Subjects & Characteristic of AFP & Outcomes & $\begin{array}{l}\text { Mean } \\
\text { followed-up } \\
\text { (months) }\end{array}$ & Controlled factors & (Refs.) \\
\hline $\begin{array}{l}\text { Sell et al } \\
(1976)\end{array}$ & 8 & $\begin{array}{l}\text { Postoperative AFP }>1,000 \\
\text { vs. AFP } \leq 1,000 \mathrm{ng} / \mathrm{ml}\end{array}$ & $\begin{array}{l}1 \text {-year OS and } \\
1 \text {-year RFS }\end{array}$ & 14 & $\begin{array}{l}\text { Primary surgery and } \\
\text { AFP determination }\end{array}$ & (11) \\
\hline $\begin{array}{l}\text { Talerman et al } \\
\text { (1978) }\end{array}$ & 9 & $\begin{array}{l}\text { Postoperative AFP }>1,000 \\
\text { vs. AFP } \leq 1,000 \mathrm{ng} / \mathrm{ml}\end{array}$ & $\begin{array}{l}\text { 2-year OS and } \\
\text { 2-year RFS }\end{array}$ & 24 & Primary surgery & (12) \\
\hline $\begin{array}{l}\text { Sessa et al } \\
(1987)\end{array}$ & 13 & $\begin{array}{l}\text { Postoperative AFP }>1,000 \\
\text { vs. AFP } \leq 1,000 \mathrm{ng} / \mathrm{ml}\end{array}$ & 2-year RFS & 36 & $\begin{array}{l}\text { Primary surgery and } \\
\text { combination chemotherapy }\end{array}$ & (13) \\
\hline $\begin{array}{l}\text { Nogales et al } \\
(1996)\end{array}$ & 6 & $\begin{array}{l}\text { Postoperative AFP }>1,000 \\
\text { vs. AFP } \leq 1,000 \mathrm{ng} / \mathrm{ml}\end{array}$ & $\begin{array}{l}1 \text {-year OS and } \\
1 \text {-year RFS }\end{array}$ & 14 & Primary surgery & $(15)$ \\
\hline $\begin{array}{l}\text { Davidoff et al } \\
\text { (1996) }\end{array}$ & 6 & $\begin{array}{l}\text { Postoperative AFP elevated } \\
\text { vs. AFP normal }\end{array}$ & $\begin{array}{l}\text { 2-year OS and } \\
\text { 2-year RFS }\end{array}$ & 53 & $\begin{array}{l}\text { Primary surgery and } \\
\text { combination chemotherapy }\end{array}$ & $(16)$ \\
\hline $\begin{array}{l}\text { Chen et al } \\
\text { (1997) }\end{array}$ & 6 & $\begin{array}{l}\text { Postoperative AFP }>1,000 \\
\text { vs. AFP } \leq 1,000 \mathrm{ng} / \mathrm{ml}\end{array}$ & $\begin{array}{l}1 \text {-year OS and } \\
1 \text {-year RFS }\end{array}$ & 12 & $\begin{array}{l}\text { Primary surgery and } \\
\text { combination chemotherapy } \\
\text { Liver metastasis }\end{array}$ & $(17)$ \\
\hline $\begin{array}{l}\text { Mitchell et al } \\
\text { (1999) }\end{array}$ & 41 & $\begin{array}{l}\text { Postoperative AFP }>1,000 \\
\text { vs. AFP } \leq 1,000 \mathrm{kU} / 1\end{array}$ & 2-year RFS & 68 & $\begin{array}{l}\text { Platinum-based } \\
\text { chemotherapy }\end{array}$ & (8) \\
\hline $\begin{array}{l}\text { de La Motte Rouge } \\
\text { et al (2011) }\end{array}$ & 73 & $\begin{array}{l}\text { Postoperative AFP }>1,000 \\
\text { vs. AFP } \leq 1,000 \mathrm{ng} / \mathrm{ml}\end{array}$ & $\begin{array}{l}5 \text {-year OS and } \\
5 \text {-year RFS }\end{array}$ & 71 & Primary surgery & (9) \\
\hline
\end{tabular}

AFP, $\alpha$-fetoprotein; OS, overall survival; RFS, relapse-free survival. 
A Study

ID

$$
\text { a }
$$

Sell (1976)

Talerman (1978)

Nogales (1996)

Chen (1997)

de La Motte Rouge (2011)

Subtotal ( 1 -squared $=0.0 \%, P=0.595$ )

b

Davidoff (1996)

Subtotal (l-squared $=. \%, P=$.)

Overall (I-squared $=0.0 \%, P=0.732$ )

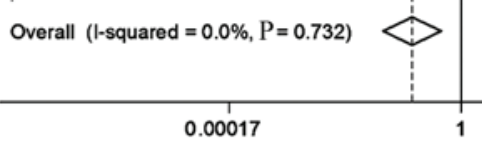

B Study

ID

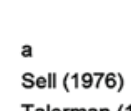

Sell (1976)

Sessa (1987)

Nogales (1996)

Chen (1997)

de La Motte Rouge (2011)

Subtotal ( 1 -squared $=0.0 \%, P=0.623$ )

b

Davidoff (1996)

Mitchell (1999)

Subtotal (I-squared $=0.0 \%, P=0.710$ )

Overall (1-squared $=0.0 \%, P=0.779$ )

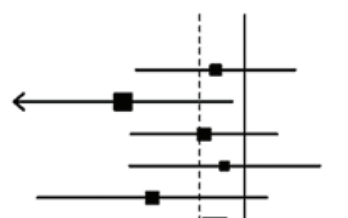

OR $(95 \% \mathrm{Cl})$

$0.01(0.00,0.62) \quad 24.21$

$0.20(0.01,6.66) \quad 8.41$

$0.03(0.00,2.27) \quad 11.10$

$0.24(0.05,1.19) \quad 39.80$

$0.16(0.05,0.50) \quad 91.59$

$0.20(0.01,6.66) \quad 8.41$

$0.20(0.01,6.66) \quad 8.41$

$0.16(0.05,0.48) \quad 100.00$

$0.33(0.02,6.65) \quad 5.53$

$0.01(0.00,0.62) \quad 16.60$

$0.21(0.01,3.37) \quad 7.95$

$0.47(0.01,16.89) \quad 3.46$

$0.03(0.00,2.27) \quad 7.61$

$0.32(0.08,1.28) \quad 29.32$

$0.21(0.08,0.57) \quad 70.47$

$0.20(0.01,6.66) \quad 5.77$

$0.09(0.01,0.85) \quad 23.76$

$0.11(0.02,0.73) \quad 29.53$

$0.18(0.08,0.43) \quad 100.00$

Figure 4. Forest plots of subgroup meta-analysis in different design methods. (A) Effect of $\alpha$-fetoprotein (AFP) level $>1,000$ vs. $\leq 1,000$ ng/ml on overall survival. (B) Effect of AFP level $>1,000 \mathrm{ng} / \mathrm{ml}$ vs. $\leq 1,000 \mathrm{ng} / \mathrm{ml}$ on relapse-free survival.

generally considered that the initial therapy for the majority of the patients should be a surgical intervention with comprehensive staging, so that a histological diagnosis and appropriate staging may be obtained $(1,6)$. Tumor stage and the amount of residual tumor significantly affect prognosis. Certain authors have reported that tumor stage is a significant prognostic factor $(3,21,22)$. Over the last few decades, fertility-sparing surgery has been the standard management of patients desiring fertility preservation, regardless of disease stage. Conservative surgery was not shown to affect the survival figures $(10,23,24)$.

OYSTs are characterized by a high malignant potential, but are also highly chemosensitive. It was reported that 3 courses of bleomycin, etoposide and cisplatin (BEP) was the current standard adjuvant therapy, with 4 courses of BEP recommended in case of bulky residual disease following surgery $(8,25,26)$. An effective postoperative chemotherapy regimen (BEP regimen) following surgery is a prognostic factor at least as significant as stage in these chemosensitive tumors (27). Our meta-analysis demonstrated that postoperative AFP was a prognostic factor in patients with OYST. Postoperative AFP was found to be correlated with OS and RFS. A high postoperative AFP level was associated with a worse OS $(\mathrm{OR}=0.16,95 \% \mathrm{CI}$ : 0.05-0.48) and RFS (OR=0.18, 95\% CI: 0.08-0.43) compared to a low postoperative AFP level in patients with OYST, possibly because a high AFP level postoperatively suggests that the tumor was not completely resected. A number of factors may lead to incomplete tumor resection, such as inappropriate surgical approach, high degree of tumor invasion and metastatic spread. In general, patients with more residual tumor will exhibit higher postoperative AFP levels. Moreover, the amount of residual tumor was shown to be a significant prognostic factor $(1,6)$.

To date, we demonstrated that high postoperative AFP levels were associated with worse OS and RFS compared to low postoperative AFP levels in patients with OYST. According to the groups from all studies that were divided by AFP level ( $>1,000 \mathrm{vs} . \leq 1,000 \mathrm{ng} / \mathrm{ml}$ ), except in the studies by Davidoff et al (16) and Mitchell et al (8), we performed a subgroup analysis and observed that a postoperative AFP level of $>1,000 \mathrm{ng} / \mathrm{ml}$ was associated with a decrease in $\mathrm{OS}(\mathrm{OR}=0.16$, 95\% CI: $0.05-0.50)$ and RFS (OR=0.21, 95\% CI: 0.08-0.57). A postoperative AFP level of $>1,000 \mathrm{ng} / \mathrm{ml}$ was associated with a worse OS and RFS compared to an AFP level of $\leq 1,000 \mathrm{ng} / \mathrm{ml}$ in patients with OYST. Accordingly, we concluded that postoperative AFP level $>1,000 \mathrm{ng} / \mathrm{ml}$ was associated with poor prognosis in patients with OYST. 
The sensitivity analysis demonstrated that the results for preoperative AFP and OS were not robust, as the study by Umezu et al (18) exhibited significant heterogeneity. However, the Umezu et al (18) study did not affect the overall results. Furthermore, the results for postoperative AFP and outcome were robust.

A number of factors, which were difficult to evaluate, may influence the effect estimates, such as sample size, study design, characteristics of AFP, outcomes and duration of follow-up. Of note, there was no heterogeneity among the studies we observed using statistical analysis. Additionally, an almost symmetric inverted funnel shape was displayed by all the studies, indicating that publication bias was unlikely.

There were several limitations to our meta-analysis. First, due to the rarity of this type of tumor, our research included only a limited amount of cases and discussed two types of OYST (pure and mixed OYST) rather than a single type (pure OYST). Mixed OYSTs exhibit different biological or clinical characteristics compared to pure OYSTs, which may affect the results. More data are required to determine the similarities and differences between pure and mixed OYSTs. Second, the determination of a high AFP level standard $(>1,000 \mathrm{ng} / \mathrm{ml})$ in our study was dependent on a single measurement (which was used in most studies). This standard may be inaccurate. In the future, a more accurate standard must be determined based on accumulation of research data.

In conclusion, OYST is a rare malignancy encountered in young women and AFP is a useful tumor marker for detecting OYST. The postoperative, but not the preoperative, AFP level was found to be a prognostic factor in patients with OYST. High postoperative AFP levels were associated with a decrease in OS and RFS. In particular, a postoperative AFP level of $>1,000 \mathrm{ng} / \mathrm{ml}$ was associated with a worse OS and RFS compared to an AFP level of $\leq 1,000 \mathrm{ng} / \mathrm{ml}$ in patients with OYST. Therefore, a postoperative AFP level of $>1,000 \mathrm{ng} / \mathrm{ml}$ was identified as an indicator of poor prognosis in patients with OYST.

\section{Acknowledgements}

This study was supported by the Natural Science Foundation of Zhejiang Province of China (grant no. Y2100593).

\section{References}

1. Kawai M, Kano T, Furuhashi Y, et al: Prognostic factors in yolk sac tumors of the ovary. A clinicopathologic analysis of 29 cases. Cancer 67: 184-192, 1991

2. Dallenbach P, Bonnefoi H, Pelte MF and Vlastos G: Yolk sac tumours of the ovary: an update. Eur J Surg Oncol 32: 1063-1075, 2006.

3. Kurman RJ and Norris HJ: Endodermal sinus tumor of the ovary: a clinical and pathologic analysis of 71 cases. Cancer 38: 2404-2419, 1976.

4. Jimerson GK and Woodruff JD: Ovarian extraembryonal teratoma. I. Endodermal sinus tumor. Am J Obstet Gynecol 127: 73-79, 1977.

5. Ayhan A, Taskiran C, Bozdag G, Altinbas S, Altinbas A and Yuce K: Endodermal sinus tumor of the ovary: the Hacettepe University experience. Eur J Obstet Gynecol Reprod Biol 123: 230-234, 2005
6. Nawa A, Obata N, Kikkawa F, et al: Prognostic factors of patients with yolk sac tumors of the ovary. Am J Obstet Gynecol 184: 1182-1188, 2001.

7. Gershenson DM, Del Junco G, Herson J and Rutledge FN: Endodermal sinus tumor of the ovary: the M.D. Anderson experience. Obstet Gynecol 61: 194-202, 1983.

8. Mitchell PL, Al-Nasiri N, A'Hern R, et al: Treatment of nondysgerminomatous ovarian germ cell tumors: an analysis of 69 cases. Cancer 85: 2232-2244, 1999.

9. de La Motte Rouge T, Pautier P, Rey A, et al: Prognostic factors in women treated for ovarian yolk sac tumour: a retrospective analysis of 84 cases. Eur J Cancer 47: 175-182, 2011.

10. Tong X, You Q, Li L, et al: Prognostic factors of patients with ovarian yolk sac tumors: a study in Chinese patients. Onkologie 31: 679-684, 2008.

11. Sell A, Sogaard H and Norgaard-Pedersen B: Serum alpha-fetoprotein as a marker for the effect of post-operative radiation therapy and/or chemotherapy in eight cases of ovarian endodermal sinus tumour. Int J Cancer 18: 574-580, 1976.

12. Talerman A, Haije WG and Baggerman L: Serum alpha fetoprotein (AFP) in diagnosis and management of endodermal sinus (yolk sac) tumor and mixed germ cell tumor of the ovary. Cancer 41: 272-278, 1978.

13. Sessa C, Bonazzi C, Landoni F, Pecorelli S, Sartori E and Mangioni C: Cisplatin, vinblastine, and bleomycin combination chemotherapy in endodermal sinus tumor of the ovary. Obstet Gynecol 70: 220-224, 1987.

14. Sasaki H, Furusato M, Teshima S, et al: Prognostic significance of histopathological subtypes in stage I pure yolk sac tumour of the ovary. Br J Cancer 69: 529-536, 1994.

15. Nogales FF, Bergeron C, Carvia RE, Alvaro T and Fulwood HR: Ovarian endometrioid tumors with yolk sac tumor component, an unusual form of ovarian neoplasm. Analysis of six cases. Am J Surg Pathol 20: 1056-1066, 1996.

16. Davidoff AM, Hebra A, Bunin N, Shochat SJ and Schnaufer L: Endodermal sinus tumor in children. J Pediatr Surg 31: 1075-1079, 1996.

17. Chen RJ, Huang SC, Chow SN, Hsieh CY, Lin MC and Hsu HC: Influence of chemotherapy or liver metastasis on the immunoelectrophoretic discrimination of alpha-fetoprotein from yolk sac tumor. Int J Gynecol Cancer 7: 486-489, 1997.

18. Umezu T, Kajiyama H, Terauchi M, et al: Long-term outcome and prognostic factors for yolk sac tumor of the ovary. Nagoya $\mathbf{J}$ Med Sci 70: 29-34, 2008.

19. Whiting PF, Rutjes AW, Westwood ME, et al: QUADAS-2: a revised tool for the quality assessment of diagnostic accuracy studies. Ann Intern Med 155: 529-536, 2011.

20. Egger M, Davey Smith G, Schneider M and Minder C: Bias in meta-analysis detected by a simple, graphical test. BMJ 315: 629-634, 1997.

21. Gershenson DM, Del Junco GD, Copeland LJ and Rutledge FN: Mixed germ cell tumors of the ovary. Obstet Gynecol 64: 200-206, 1984.

22. Morris HH, La Vecchia C and Draper GJ: Endodermal sinus tumor and embryonal carcinoma of the ovary in children. Gynecol Oncol 21: 7-17, 1985.

23. Bakri YN, Ezzat A, Akhtar, Dohami and Zahrani: Malignant germ cell tumors of the ovary. Pregnancy considerations. Eur J Obstet Gynecol Reprod Biol 90: 87-91, 2000.

24. Low JJ, Perrin LC, Crandon AJ and Hacker NF: Conservative surgery to preserve ovarian function in patients with malignant ovarian germ cell tumors. A review of 74 cases. Cancer 89: 391-398, 2000

25. Williams S, Blessing JA, Liao SY, Ball H and Hanjani P: Adjuvant therapy of ovarian germ cell tumors with cisplatin, etoposide, and bleomycin: a trial of the Gynecologic Oncology Group. J Clin Oncol 12: 701-706, 1994.

26. Gershenson DM, Morris M, Cangir A, et al: Treatment of malignant germ cell tumors of the ovary with bleomycin, etoposide, and cisplatin. J Clin Oncol 8: 715-720, 1990.

27. Cicin I, Saip P, Guney N, et al: Yolk sac tumours of the ovary: evaluation of clinicopathological features and prognostic factors. Eur J Obstet Gynecol Reprod Biol 146: 210-214, 2009. 